\title{
Progesterone for the prevention of preterm birth: indications, when to initiate, efficacy and safety
}

\author{
Helen Y How \\ Baha M Sibai \\ Division of Maternal Fetal Medicine, \\ Department of Obstetrics \\ and Gynecology, University \\ of Cincinnati, Cincinnati, OH USA
}

\begin{abstract}
Preterm birth is the leading cause of neonatal mortality and morbidity and long-term disability of non-anomalous infants. Previous studies have identified a prior early spontaneous preterm birth as the risk factor with the highest predictive value for recurrence. Two recent double blind randomized placebo controlled trials reported lower preterm birth rate with the use of either intramuscular 17 alpha-hydroxyprogesterone caproate (IM 17OHP-C) or intravaginal micronized progesterone suppositories in women at risk for preterm delivery. However, it is still unclear which high-risk women would truly benefit from this treatment in a general clinical setting and whether socio-cultural, racial and genetic differences play a role in patient's response to supplemental progesterone. In addition the patient's acceptance of such recommendation is also in question. More research is still required on identification of at risk group, the optimal gestational age at initiation, mode of administration, dose of progesterone and long-term safety.
\end{abstract}

Keywords: preterm birth prevention, 17-alpha-hydroxyprogesterone caproate

\section{Introduction to management and issues of preterm birth}

Premature delivery, defined as birth prior to 37 weeks, remains one of the major problems that lead to perinatal morbidity and mortality in the developed countries. ${ }^{1}$ It affects approximately $12.5 \%$ of all deliveries in the US; one third of these occur before 34 weeks' gestation. ${ }^{2,3}$ These numbers reflect an increase of $30 \%$ over the preterm birth (PTB) rate reported in $1981^{3}$ and equates to nearly 500,000 PTBs each year. This prematurity rate has been increasing probably as a result of delayed child bearing and to the increased frequency of multifetal pregnancies from assisted reproductive technology. ${ }^{4,5}$ The rate of PTB is substantially higher in African American and Hispanics as compared to Caucasians. ${ }^{6,7}$

Prematurity causes an estimated $70 \%$ of all neonatal deaths of non-anomalous infants in the United States. ${ }^{8}$ Neonatal mortality is directly correlated with gestational age (GA) at delivery. The mortality rate for infants born at less than 32 weeks' gestation is almost 70 times the rate of a term infant, ${ }^{9}$ and for infants born less than 37 weeks' gestation it is 15 times the term infant rate (2.6/1000 live births). Reported neonatal morbidity is also a major concern, especially for infants born at less than 32 weeks' gestation. Neonatal complications include intraventricular hemorrhage, necrotizing enterocolitis, respiratory distress syndrome, bronchopulmonary dysplasia, jaundice and anemia. ${ }^{3}$ Economically, care for these infants is responsible for an estimated US $\$ 51,600$ investment per child in neonatal care, contributing more than US\$26 billion to annual healthcare costs in the US. ${ }^{3}$ Among the infants who survive, $10 \%-15 \%$ are burdened with significant handicaps, such as cerebral palsy, mental retardation, retinopathy, or hearing impairment. ${ }^{10}$ More importantly, low birth weight infants who 
are spared significant neonatal morbidity are at higher risk for cardiovascular disease (myocardial infarction, stroke, and hypertension) and diabetes as adults. ${ }^{10}$

Preterm delivery (PTD) is due to either spontaneous preterm labor (PTL) (40\%-50\%), spontaneous preterm premature rupture of membranes (PPROM) (25\%-40\%), or obstetrically indicated PTD $(20 \%-25 \%)$ as a result of maternal, placental or fetal complications (preeclampsia, renal disease, diabetes mellitus with vasculopathy, placenta previa or abruptio, and fetal growth restriction). ${ }^{11}$

Risks factors for spontaneous PTD have been reported by members of the NICHD maternal-Fetal Medicine units network among 2929 pregnant women enrolled in the preterm prediction observational study. ${ }^{12}$ Risks factors analyzed included maternal demographics, previous history of PTD, presence or absence of fetal fibronectin, bacterial vaginosis or shortened cervical length by ultrasound. ${ }^{13-16}$ In addition, members of the above group also reported the use of antibiotics versus placebo in treating bacterial vaginosis or trichomonas, or upper genital infection (positive fetal fibronectin) in the prevention of PTD. The results of these trials revealed no differences in PTD rates with the use of antibiotics. ${ }^{17,18}$

There are numerous studies suggesting a strong association between the presence of a short cervix in the mid-trimester and subsequent PTD at $<37$ weeks and $<35$ weeks' gestation. ${ }^{14,19-21}$ In response to these studies, several authors recommended or reported on the use of cerclage for prevention of PTB in women with shortened cervix. The results of these studies did not conclusively show cerclage to be efficacious. $^{22-25}$ There are several protocols and regimens to treat women with PTL. Many of these include bed rest, and the use of tocolytics agents such as magnesium sulfate, betamimetics, or indomethacin. The results of these studies reveal a beneficial effect in prolonging gestation for 48 hours, but without reduction in PTD rates. ${ }^{26-29}$

\section{The role of socioeconomic status and ethnic origin and PTD}

Social disadvantage whether defined by occupation, income, or degree of education, is associated with an increased risk of PTD. ${ }^{30-33}$ The reasons for this trend are not clear, but possible explanations include worse nutritional status, increased frequency of cigarette smoking, greater use of recreational drugs such as cocaine, higher rates of fetal growth restriction, poorer quality and quantity of antenatal care, higher frequency of genital tract infection, physically demanding work, and higher levels of adverse psychological factors.
Attempts to understand rates of PTD in lower socioeconomic groups have not yet yielded benefit in terms of providing clues to the cause of PTB in general. ${ }^{30}$ Furthermore, attempts at intervention by improvement of social support mechanisms in this population have neither resulted in a decrease in the rates of PTD nor in improvement in outcome by any perinatal measures. ${ }^{34,35}$

The PTB rate for black women is almost twice that for white women of comparable age in the USA irrespective of socioeconomic status. ${ }^{36}$ This racial gap has slightly diminished during the past 10 years largely due to an increase in PTD rates for white infants; ${ }^{36}$ although PTB rates have increased by $3.6 \%$ in black women (from $15.5 \%$ in 1975 to $16 \%$ in 1995$)$, a rise of $22.3 \%$ in white women $(6.9 \%$ to $8.4 \%$ ) has been reported over the same interval. ${ }^{37}$ In black primigravid women in USA, rates of PTD increased from 1975 to 1990 and began to decline thereafter, whereas among white primigravid women, the rates rose between 1975 and 1995. ${ }^{38}$ Why this difference exists is not clear, but since the preponderance of preterm deliveries in the black population arose in the idiopathic PTL group, it can not be explained by variation in socio-economic status and hence is suggestive of a biological variation.

\section{The role of acculturation and birth outcomes}

Acculturation is a process that involves several variables. These variables include family roles, gender roles, and socioeconomic variables. The degree to which one acculturates may affect their behavior. A change in behavior can have an effect on health outcomes. Recent efforts to understand differences between US and foreign-born women of the same ethnicity focus on difference in behavior and health insurance, both of which are related to more general differences in acculturation. There is, for instance, significant variation in smoking, and illicit drug use by nativity. Pregnant Latinos in California are between five and 10 times more likely to use illicit drugs if they were born within as compared to outside of US. ${ }^{39}$ A similar pattern has been observed among the general population of Latinos in US. . $^{4,41}$ Moreover, the extent of drug use was directly correlated with the degree of acculturation as measured by English language usage.

Other explanations for the birth outcome advantage enjoyed by foreign-born women include a more supportive family structure. The proportion of births to unmarried women, a possible proxy for family cohesion, is generally higher among US, as compared to foreign-born Latinos. ${ }^{42-44}$ 
More generally, researchers have suggested that Latin culture, as proxied by mother's birthplace or English Language usage, is protective of immigrant health. ${ }^{45,46}$

\section{Preterm birth prevention program}

Most PTB prevention programs have attempted to identify women who are likely to deliver prematurely based on the presence of numerous risk factors, ${ }^{11,47-49}$ including low socioeconomic status, maternal age less than 18 or greater than 40 years, increasing parity, race, previous preterm labor and delivery, multiple gestation, uterine malformations, and bacterial vaginosis..$^{50-53}$ The most important of these factors is a history of PTD, ${ }^{54-56}$ which may be influenced by genetic and environmental determinants. ${ }^{57}$ However, the intergenerational predisposition to PTB has not been well established, with some investigators finding a significant effect ${ }^{58-60}$ and others finding no effect. ${ }^{61}$

\section{Familial and intergenerational influence of PTB}

The genetic basis for spontaneous preterm labor and delivery is complex and undoubtedly cannot be explained by a single gene polymorphism. It has been estimated that there are approximately 200,000 single nucleotide polymorphisms within the coding regions of the human genes. ${ }^{62}$ In addition; there are many repetitive DNA elements of variable length in the human genome. Different polymorphisms may have an additive or synergistic effect on the risk for severity of the disease. ${ }^{63}$ Furthermore individual combinations of polymorphisms may up-or down-regulate each other. ${ }^{64}$ This may partially explain the reason that a certain polymorphism is associated with spontaneous PTB in one ethnic group, but not in a different ethnic group.

There is also strong evidence of familial or intergenerational influence on PTD. A study from Scotland ${ }^{65}$ found that sisters of women who had delivered preterm low birth weight infants were more likely to have a preterm infant than the sisters of women who had delivered term growth-retarded infants. A Norwegian study ${ }^{61}$ found no significant association between mother and offspring preterm status. However, a US study showed an increased risk of PTB among women who themselves were born before 37 weeks' gestation. ${ }^{66}$ A previous history of PTD is one of the most important risk factors for a subsequent PTD. ${ }^{67}$ It has also been shown that the risk of PTD increases substantially with the number of previous preterm infants. Bakketeig and coworkers ${ }^{68}$ showed that the risk of PTD (defined as $<36$ weeks in their study) was $14.3 \%$ if the first birth was preterm and $28.1 \%$ for the third pregnancy if both prior births were preterm. The risk of recurrence did not appear to be affected by the presence of medical complications, the length of the inter-pregnancy interval, or fetal survival. Vatten et $\mathrm{al}^{69}$ reported that after adjustment for maternal age and education, interval between births, and the decade of birth, the risk of adverse pregnancy outcomes was higher in the second birth for women who changed partners between the first 2 births compared with women who had the same partner for both births. The relative risk of PTB before 37 weeks of gestation was 2.0 (95\% CI 1.9-2.1), for low birth weigh of less than 2,500 $\mathrm{g}$ the relative risk was 2.5 (95\% CI 2.3-2.6), and for infant mortality the relative risk was 1.8 (95\% CI 1.6-2.1). Similarly, paternal inheritance has also been implicated, when studying a group of 128,239 women who had two consecutive births; Li et $\mathrm{al}^{70}$ observed that changing partners resulted in a $33 \%$ reduction in the risk of spontaneous PTD in women whose first pregnancy led to delivery before 34 weeks of gestation. In contrast, among women whose first pregnancy resulted in birth after 36 weeks of gestation, changing partners led to a $16 \%$ increase in the risk of early PTD during the subsequent pregnancy. However, this association could not be confirmed by a Danish study that involved 14,147 index fathers who had at least 1 child who was delivered before 37 weeks of gestation. ${ }^{71}$

In summary, the causes of PTL are multifactorial, complex, and poorly understood. As a result, there are no tests or assessment measures available that accurately predict PTB.

\section{Review of pharmacology, mode of action of progesterone and in particular 17 OHP-C Role of progesterone and initiation of labor}

The role of progesterone in pregnancy is unclear; however, it is known that the effects of progesterone on the myometrium are 2-fold: it suppresses the action of estrogen by inhibiting the replacement of cytosolic estrogen receptors and it exerts a direct effect on the biosynthetic processes of the uterus through its own cellular receptor. ${ }^{72-74}$ Thus the contractile capacity is maintained under the influence of progesterone, as indicated by the development of tension in the electrically stimulated uterus of progesterone-treated rabbits or rats.

The ability of progesterone to maintain uterine quiescence during pregnancy has been shown in lower mammalian species. ${ }^{75,76}$ In these species, progesterone withdrawal is a necessary step in the events leading to parturition. 
Administration of exogenous progesterone to ewe blocked this sequence of events after glucocorticoid infusion to the fetus and effectively prevented the progression to labor and delivery. ${ }^{77,78}$ In women, the role of progesterone withdrawal as a mechanism for parturition has been questioned because maternal, fetal, and amniotic fluid concentrations of progesterone are sustained before the onset of labor and delivery. ${ }^{79,80}$ Nevertheless, the progesterone withdrawal theory remains a leading hypothesis because no other mechanism for the onset of human parturition has been definitively established and because synthetic antiprogestins stimulate myometrial contractions $^{81,82}$ whereas inhibitors of 3B-hydroxysteroid dehydrogenase, which lower systemic progesterone levels, induce labor and delivery in women ${ }^{83}$ and in monkeys. ${ }^{84}$ There is also an associated increase in the expression of a range of "pro-labor" genes, which are normally repressed by the presence of progesterone. ${ }^{85}$

Several explanations for "functional" progesterone withdrawal have been proposed, such as loss of progesterone receptors or change in receptor isoform expression, binding of progesterone to a high affinity protein and therefore a reduction in free active steroid, ${ }^{86-87}$ production of a local antiprogestin, sequestration of progesterone into lipoproteins or localization of the progesterone withdrawal to the avascular fetal membranes so that a decrease is not detected in the circulation. ${ }^{88}$ None of these hypotheses has been proven, and so the questions remains, how does "functional withdrawal" of progesterone prior to human labor occur? Conversely, how does progesterone replacement stops labor?

Progestins are available in natural or synthetic formulations for oral, intramuscular (IM) or vaginal administration in the form of suppository or gel. Natural (micronized) progesterone is an exact duplicate of the progesterone produced in the corpus luteum and placenta. It is therefore more readily metabolized by the body and is associated with minimal side effects. ${ }^{89}$ The two natural progesterone include progesterone and 17-hydroxyprogesterone. The plasma concentration will depend on the dose and route of administration, ${ }^{90} \mathrm{eg}$, oral (3-6ng/mL@100mg and 30ng/mL@200mg),transdermal (3 ng/mL@45 mg), vaginal cream (19 ng/mL@300mg) or gel (3.9 ng/mL@ @ 90 mg), vaginal (10-19 ng/mL @ 100 mg, 17-34 ng/mL @ 400 mg) or rectal (15-52 ng/mL @ 100 mg) suppository, IM (40-50 ng/mL @ 100 mg) and sublingual(5 ng/mL@10 mg dose). The time to peak plasma concentration is longest with90mg vaginal gel@7 hours and shortest with 200 mg oral micronized progesterone @ 0.8 hour. The vaginal suppository (100 mg and $400 \mathrm{mg}$ ) and
$100 \mathrm{mg}$ rectal suppository is about 4 hours and the IM route (100 mg) takes about 2-8 hours. ${ }^{90}$

Synthetic progestins are progesterone derivatives and 19 nortestosterone derivatives; its chemical structure is very similar to that of the natural progesterone. 17 alpha hydroxyprogesterone caproate (17OHP-C) is a 17-hydroxyprogesterone derivative, it is the most commonly used synthetic progestin given intramuscularly to prevent PTB. ${ }^{89}$ It has been isolated from both adrenal glands and corpora lutea. The synthetic caproate ester is inactive when given by mouth but works as a long-acting progestin when administered intramuscularly. Pharmacokinetic studies have shown that once-weekly IM.

Administration of $17 \mathrm{OHPC}$ would provide continuous systemic serum levels of 17OHP-C. The half-life of 17OHP-C was estimated to be approximately 7.8 days. ${ }^{91}$ The route of administration plays an important role in the drug's safety and efficacy profile. Oral progesterone has not been used for prevention of PTB because of its first-pass hepatic metabolism, lack of efficacy data, high side-effect profile, extreme variability in plasma concentrations. Transvaginal administration of progesterone avoids first-pass hepatic metabolism and is associated with rapid absorption, high bioavailability, and local endometrial effects. ${ }^{92}$ It has been shown to provide higher and more sustained progesterone concentrations and is the preferred route of administration in many cases. ${ }^{93-95}$ Although this route offers no local pain and few side effects, it is associated with variable blood concentrations. ${ }^{93,95}$

\section{Efficacy studies}

\section{Earlier trials: prior to year 2003}

Earlier small trials using 17OHP-C showed mixed results; 4 trials reported benefit, ${ }^{96-99}$ whereas 2 trials reported no benefit ${ }^{100,101}$ in reducing the risk of PTD. A meta-analysis over a decade ago ${ }^{102}$ showed that progesterone was beneficial in reducing PTL: odds ratio 0.43 (95\% CI 0.20, 0.89); PTB: odds ratio $0.50(95 \%$ CI $0.30,0.85)$ and low birth weight $(<2500 \mathrm{~g})$ : odds ratio $0.50(95 \%$ CI $0.27,0.80)$. Because of these encouraging results, several trials were designed and conducted to evaluate the potential benefits of various progesterone preparations in preventing PTB in women at high risk for this complication.

\section{Recent trials: year 2003 till present}

Two recent published double blind randomized placebocontrolled trials on singleton gestation reported lower PTB rate with the use of either progesterone vaginal suppositories $^{103}$ or intramuscular (IM) $17 \mathrm{OHP}-\mathrm{C}^{104}$ in women at risk for PTD (Table 1). Since the publication of these two 
Table I Randomized double-blind placebo controlled trials of the efficacy of progesterone for the prevention of PTB (years 2003-2007)

\begin{tabular}{|c|c|c|c|c|c|c|}
\hline \multirow[t]{2}{*}{ Authors (year) } & \multirow{2}{*}{$\begin{array}{l}\text { Progest agent/dose/ } \\
\text { duration }\end{array}$} & \multirow{2}{*}{$\begin{array}{l}\text { GA @ initiation } \\
\text { (week) }\end{array}$} & \multicolumn{2}{|c|}{ \# of subjects } & \multicolumn{2}{|c|}{$\%$ preterm deliveries } \\
\hline & & & Progest & Placebo & Progest & Placebo \\
\hline $\begin{array}{l}\text { Meis et al }{ }^{104} \\
(2003)\end{array}$ & $\begin{array}{l}\text { I7 OHP-C, weekly } \\
\text { IM } 250 \text { mg. up to } \\
36.9 \text { wks }\end{array}$ & 16-20.9 singleton & 310 & $153^{\mathrm{a}}$ & $\begin{array}{l}<37 \text { wk: } 36.3 \\
<35 \text { wk: } 20.6 \\
<32 \text { wk: I I.4 }\end{array}$ & $\begin{array}{l}54.9 \\
30.7 \\
19.6\end{array}$ \\
\hline $\begin{array}{l}\text { da Fonseca et al }{ }^{103} \\
(2003)\end{array}$ & $\begin{array}{l}\text { Natural micronized } \\
\text { vaginal non-bioadhesive } \\
\text { progest. suppositories, } \\
100 \mathrm{mg} \text { daily, up to } \\
34 \text { wks }\end{array}$ & 24-34 singleton & 72 & 70 & $\begin{array}{l}<37 \text { wk: } 13.8 \\
<34 \text { wk: } 2.8\end{array}$ & $\begin{array}{l}28.5 \\
18.6\end{array}$ \\
\hline $\begin{array}{l}\text { O’Brien et al }{ }^{106} \\
(2007)\end{array}$ & $\begin{array}{l}\text { Natural micronized } \\
\text { vaginal bioadhesive } \\
\text { progest. gel, } 90 \mathrm{mg} \\
\text { daily, up to } 36.9 \mathrm{wks}\end{array}$ & 18-22.9 singleton & 309 & 302 & $\begin{array}{l}\leq 37 w k: 41.7 \\
\leq 35 w k: 22.7 \\
\leq 32 w k: 10.0 \\
\leq 28 w k: 3.2\end{array}$ & $\begin{array}{l}40.7 \\
26.5 \\
11.3 \\
3.0\end{array}$ \\
\hline $\begin{array}{l}\text { de Fonseca et al }{ }^{108} \\
(2007)\end{array}$ & $\begin{array}{l}\text { Natural micronized } \\
\text { vaginal non-bioadhesive } \\
\text { progest. capsule, } \\
200 \text { mg daily up to } \\
33.9 \text { wks }\end{array}$ & $\begin{array}{l}20-25 \text { singleton } \\
(\sim 90 \%) \text { and twin }\end{array}$ & 125 & $125^{\mathrm{b}}$ & $<34$ wk: 9.2 & 34.4 \\
\hline $\begin{array}{l}\text { Rouse et al }{ }^{107} \\
(2007)\end{array}$ & $\begin{array}{l}\text { I7 OHP-C, weekly } \\
\text { IM } 250 \mathrm{mg} \text {, up to } \\
35 \text { wks }\end{array}$ & 16-20.9 twin & 325 & 330 & $\begin{array}{l}<37 \text { wk: } 69.5 \\
<32 \text { wk: } 6.9 \\
<27 \text { wk: } 8.0\end{array}$ & $\begin{array}{l}70.3 \\
14.5 \\
6.1\end{array}$ \\
\hline
\end{tabular}

aPlacebo used was castor oil.

'Placebo used was safflower oil.

Abbreviations: Progest, progesterone; 17 OHP-C: 17 alpha hydroxyprogesterone caproate.

double blind placebo controlled studies. ${ }^{103,104}$ The National Institute of Child Health and Development (NICHD), the American College of Obstetricians and Gynecologist (ACOG) and the March of Dime endorsed the prophylactic use of 17OHP-C in women with history of preterm deliveries, although both studies had several limitations. For example: in the da Fonseca et al study, ${ }^{103}$ the women were not started on non-bioadhesive progesterone vaginal suppository till late gestation, the mean GA at enrollment was 25.2 weeks in the placebo group and 26.5 weeks in the progesterone vaginal suppositories group. In addition, women who delivered preterm following preterm premature rupture of membranes were excluded. If these women were included in the analysis, the difference in PTB is no longer statistically significant. In the Meis et al study, ${ }^{104}$ the women enrolled had high rates of PTD, with $54.9 \%$ of the women who received the placebo injections delivering before 37 weeks of gestation. This high rate of PTD was most likely related to the history of previous preterm deliveries. The earlier in a pregnancy a PTD occurs, the greater the chance of PTD in a subsequent pregnancy. It should also be noted that the mean duration of gestation at the time of the qualifying delivery was 31 weeks, and a third of the women enrolled had had more than one previous PTD. These women were very high risk, strongly motivated and compliant. On the other hand, 17OHP-C may not be effective in women with a lower risk of PTD, and most preterm deliveries occur in women with no previous PTD. Therefore, the result of Meis et al study ${ }^{104}$ should be interpreted with caution and may not be generalizable to women with a lower risk of PTD. In addition, although 17-OHPC significantly reduced the rate of PTD among the women who received it, the rate of PTD in this group remained very high at $36.3 \%$. Thus, the identification of other causes of PTD and other methods of preventing it remains a pressing need. Another noteworthy point is that although the Meis et al study ${ }^{104}$ demonstrated a statistically significant reduction in the primary endpoint of PTB prior to 37 weeks' gestation, the reduction in PTBs prior to 35 weeks and prior to 32 weeks' gestation which are better surrogates for significant neonatal morbidity and mortality, were not statistically persuasive. In addition, the primary clinical trial did not demonstrate a significant reduction in another secondary endpoint, a composite assessment of infant mortality and morbidity. In a subsequent data analysis of the NICHD trial ${ }^{104}$ evaluating the benefit of $17 \mathrm{OHP}-\mathrm{C}$ according to the GA of previous delivery, 
Spong et $\mathrm{al}^{105}$ reported that progesterone did not significantly improve the GA at delivery in women whose earliest previous delivery was at 34-35.9 weeks' gestation. However, the recurrence of PTB was significantly less for women treated with 17OHP-C with GA at the earliest previous spontaneous PTB 20-27.9 weeks (42\% vs 63\%) and 28-33.9 weeks (34\% vs $56 \%$ ). From their data, the authors concluded that for the women with earliest previous spontaneous PTB at 20-27.9 weeks and 28-33.9 weeks, 4.7 and 4.6 women (respectively for each group) would need to be treated with $17 \mathrm{OHP}-\mathrm{C}$ to prevent one PTB.

In a multinational double blind placebo controlled trial on the use of bioadhesive progesterone vaginal gel for the prevention of PTB in 611 women, ${ }^{106}$ the findings revealed no significant differences between the progesterone vaginal gel and placebo in the rate of PTB at $<35$ weeks' gestation (Table 1). This is in contrast to the previously mentioned trial by da Fonseca et al. ${ }^{103}$ Recently, Rouse et al ${ }^{107}$ presented the NICHD network data on the use of 17OHP-C in the prevention of PTB in twins, the results showed that treatment with 17OHP-C did not reduce the rate of PTB in twins (Table 1). Potential limitations of Rouse ${ }^{107}$ trial are: 1) less than $10 \%$ of enrolled women had a history of prior PTB; and, 2) they use the same 17 OHPC dose $(250 \mathrm{mg})$ in women with twin gestation, when their plasma volume is known to be $20 \%$ greater than that in singleton gestation. More recently, da Fonseca et $\mathrm{l}^{108}$ published a randomized, double blind placebo-controlled trial of 250 women with a short cervix ( $\leq 15 \mathrm{~mm}$ by transvaginal ultrasound). The frequency of spontaneous PTB at $<34$ weeks was significantly lower in the progesterone group compared with placebo group (Table 1). This trial suggests that determination of cervical length is a powerful method for PTB risk assessment. However, until further trials, routine screening of low risk pregnant women by transvaginal ultrasound of cervical length is still not recommended, because only $1.7 \%(413 / 24,620)$ of the patients screened have short cervix in the mid trimester. ${ }^{108}$

There are 2 published observational data regarding the use of 17 OHP-C in the prevention of recurrent PTB. Rebarber et $\mathrm{al}^{109}$ in a retrospective analysis of data from 481 women who were enrolled for outpatient weekly IM 17OHP-C administrations. They found that women with elective early cessation of weekly 17 OHP-C at $<32$ weeks' gestation were significantly more likely to have spontaneous recurrent PTD at $<37$ weeks, $<35$ weeks and $<32$ weeks of gestation when compared to the women who received weekly 17 OHP-C injections until PTD or 36.9 weeks (Table 2). Discontinuation of 17OHP-C was defined as being elective when it occurred for any reason other than hospitalization for eminent delivery or an acute condition that led to delivery within 10 days. In this study, whether the elective discontinuation was patient or physician driven is not available from the database.

We performed a retrospectively analysis of database of women enrolled for outpatient 17OHP-C prophylaxis for prevention of spontaneous PTB. ${ }^{110}$ The data were divided into three groups according to the number of PTD $(1,2,>2)$ and stratified to initiation of 17OHP-C at 16-20.9 weeks and 21-26.9 weeks. We found that the rates of spontaneous PTB

Table 2 Observational studies analyzing rates of preterm delivery (PTD) (\%) according to when 17 OHP-C was discontinued, gestational age at initiation and number of previous PTD

\begin{tabular}{|c|c|c|c|c|c|}
\hline \multirow[t]{2}{*}{ Preterm labor } & \multicolumn{2}{|c|}{ Rebarber et al (2007) ${ }^{109}$} & \multicolumn{3}{|c|}{ How et al (2007) $)^{110}$} \\
\hline & $\begin{array}{l}\text { Continued till } \\
36 \text { wks } n=400^{a}\end{array}$ & $\begin{array}{l}\text { Discontinued } \\
@<32 \text { wks n = 8I }\end{array}$ & $\begin{array}{l}\text { Early initiation } \\
(16-20.9 \text { wks) } \\
\mathrm{N}=599\end{array}$ & & $\begin{array}{l}\text { Late initiation } \\
(2 \mathrm{I}-26.9 \text { wks) } \\
\mathrm{N}=307\end{array}$ \\
\hline \multirow[t]{4}{*}{$<37$ wks (\%) } & 33 & 48 & Overall & 33 & 36 \\
\hline & & & I PTD & 27 & 34 \\
\hline & & & 2 PTD & $44^{b}$ & 39 \\
\hline & & & $>2$ PTD & $59^{\mathrm{b}}$ & 39 \\
\hline \multirow[t]{4}{*}{$<35$ wks (\%) } & 14 & 31 & Overall & 13 & 14 \\
\hline & & & I PTD & 9 & 11 \\
\hline & & & 2 PTD & $23^{b}$ & 15 \\
\hline & & & $>2$ PTD & $20^{\mathrm{b}}$ & $30^{\mathrm{b}}$ \\
\hline \multirow[t]{4}{*}{$<32$ wks (\%) } & 7 & 16 & Overall & 5 & 4 \\
\hline & & & I PTD & 4 & 2 \\
\hline & & & 2 PTD & 9 & 2 \\
\hline & & & $>2$ PTD & 7 & $18^{c}$ \\
\hline
\end{tabular}

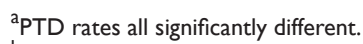

${ }_{\mathrm{P}}^{\mathrm{P}}<0.05$ vs I PTD group.

$c_{\mathrm{P}}<0.05$ vs I PTD and 2 PTD groups. 
were significantly higher in those with $\geq 2$ PTD ( $\mathrm{n}=159$, $51 \%$ vs $27 \%$ at $<37$ weeks and $21 \%$ vs $9 \%$ at $<35$ weeks in the 17OHP-C start at 16-20.9 weeks group; $18 \%$ vs $2 \%$ at $<32$ weeks in the 17 OHP-C start at 21-26.9 weeks group) as compared to those with one PTD $(\mathrm{n}=440)$ (Table 2). There were no significant differences in spontaneous PTD rates according to the time of initiation of $17 \mathrm{OHP}-\mathrm{C}$ at 16-20.9 weeks vs 21-26.9 weeks GA (Table 2). We concluded that women with history of $\geq 2$ PTD have a high risk of recurrent spontaneous PTD at $<37$ and $<35$ weeks despite 17OHP-C prophylaxis. Later second trimester initiation of $17 \mathrm{OHP}-\mathrm{C}$ prophylaxis is as effective as initiation in the early second trimester. However, these conclusions should be interpreted with caution because data such as baseline cervical length, the GA or circumstances of the prior PTB, maternal race, and complete neonatal outcomes were not available.

\section{Safety and tolerability}

Synthetic progestins, including 17OHP-C have been associated with a less desirable side-effect profile than that of natural progesterone, including mood swings, headaches, bloating, abdominal pain, perineal pain, constipation, diarrhea, nausea, vomiting, joint pain, depression, decreased sex drive, difficult or painful intercourse, nervousness, sleepiness, breast enlargement, breast pain, nucturia, dysuria, polyuria, urinary tract infection, allergy, tiredness, dizziness, genital itching, yeast infection, vaginal discharge, fever, flu-like symptoms, back pain, leg pain, sleep disorder, inflammation of a sinus, upper respiratory infection, asthma, acne and pruritus. In the Meis trial, ${ }^{104}$ the most common undesirable side effect was injection site pain (35\%), injection site swelling (17\%), urticaria $(12 \%)$, pruritus $(8 \%)$, injection site pruritus $(6 \%)$, nausea $(6 \%)$, contusion $(6 \%)$, injection site nodule $(4 \%)$, and vomiting $(3 \%){ }^{111}$

Meis et $\mathrm{al}^{104}$ and Heinonen et $\mathrm{al}^{112}$ reported a small, statistically non-significant increased in miscarriage and stillbirths in women receiving progesterone. Our retrospectively study $^{110}$ showed infrequent spontaneous abortion at $<24$ weeks' gestation $(0.9 \%)$, stillbirth $(0.5 \%)$, and neonatal death $(0.4 \%)$ in women receiving progesterone prophylaxis to prevent PTB. Further investigation is necessary to evaluate the validity of these concerns.

Data from animal studies, suggest that increased plasma levels of progesterone may influence fetal behavior and induce fetal arousal states. ${ }^{113,114}$ There are no human data regarding long term outcome of women and infants who were exposed to progesterone in-utero until the most recent article published by NICHD trial ${ }^{115}$ reporting the
4 year follow up of children exposed to 17OHP-C in utero. The children were 30-64 months of age at the time of the follow-up assessments. Of the 348 eligible surviving children, 278 (80\%) were available for evaluation (194 17OHP-C, 84 placebo). No significant differences were seen in health status and conditions, or physical exam, including genital anomalies between 17OHP-C and placebo children. Developmental screen including communication, gross motor, fine motor, problem solving, personal-social issues were not significantly different between $17 \mathrm{OHP}-\mathrm{C}$ and placebo group. There are some concerns regarding the vehicle, castor oil, used in IM 17OHP-C. The castor oil is thought to induce labor by stimulating the release of prostaglandins, which might negate the potential beneficial effect of IM 17-OHP-C. ${ }^{116}$

\section{Patient focused perspectives such as quality of life, patient satisfaction/ acceptability}

Weekly IM injections of 17 OHP-C may be undesirable to a portion of the population at risk for preterm delivery. Progesterone administered intramuscularly has been associated with several systemic and local skin complications. Some women may find transvaginal delivery to be more acceptable than injection, but others may not agree. Suppositories can be difficult to place high in the vagina and may liquefy, potentially leads to vaginal discharge, irritation, and infection. Vaginal cream and gel, which do not liquefy and are easier to apply, may alleviate some of the problems associated with transvaginal suppositories. Comparative data on the various methods of administration are thus needed to determine pharmacokinetic or tolerability differences, however, before one method can be recommended over the others.

\section{Conclusions, place in therapy}

We believe that there is a place for progesterone in the prevention of PTB. However the optimal dosage, route and timely delivery of the drug remain controversial.

Direct comparison of different progesterone formulations and routes of administration is required to identify any preferences in pharmacokinetic behavior or tolerability issues. As stated by the ACOG committee, progesterone has only been studied as a "prophylactic measure in asymptomatic women" and therefore until further studies evaluate the use of progesterone in women with other high-risk obstetric factors "it is important to restrict its use to only women with a documented history of a previous spontaneous PTB. ...."117 
At present, it is prudent to await the result of several large clinical trials. (http://content.nejm.org/egi/date/357/5/499/ DCI/1) and basic science studies supported by NICHD, March of Dimes and others to provide additional evidence-based information in the near future to expand the recommended eligibility criteria for progesterone administration. In addition, more data are needed to ensure the safety of the mother and child exposed to any of these drugs.

\section{Disclosures}

The authors have no conflicts of interest to disclose.

\section{References}

1. Anon. Practice bulletin ACOG: clinical management guidelines for obstetrician gynecologist \#31-assessment of risk factors for preterm birth. Obstet Gynecol. 2001;98:706-709.

2. Amon E. Preterm labor. In: Reece EA, Hobbins JC, editors. Medicine of the fetus and mothers. Philadelphia: Lippincott-Raven; 1999. p. 529-579.

3. Institute of Medicine of the National Academies. Preterm Birth: Causes, Consequences, and Prevention. Washington DC; National Academies Press; 2006. Accessed September 12, 2006. Available at: http://www. iom.edu/CMS/3740/25471/35813.aspx.

4. Tough SC, Newburn-Cook C, Johnston DW. Delayed childbearing and its impact on population rate changes in lower birth weight, multiple birth, and preterm delivery. Pediatrics. 2002;109(3):399-403.

5. Reynolds MM, Schieve LA, Martin JA, et al. Trends in multiple births conceived using assisted reproductive technology, united states, 1997-2000 Pediatrics. 2003;111(5):1159-1162.

6. Schieve, LA, Handler, A. Preterm delivery and perinatal death among black and white infants in a Chicago-area perinatal registry. Obstet Gynecol. 1996:88:356-363.

7. Martin JA, Hamilton BE, Ventura SJ. Births: preliminary data for 2000. Natl Vital Stat Rep. 2001;49:1-20.

8. Guyer B, Martin JA, MacDorman MF, et al. Annual summary of vital statistics-1996. Pediatrics. 1997;100:905-918.

9. March of Dimes Birth Defects Foundation. Available at: http://www. marchofdimes.com. Accessed July 11, 2005.

10. Gluckman PD, Hanson MA. Living with the past: evolution, development and patterns of disease. Science. 2004;305:1733-1736.

11. Tucker JM, Goldenberg RL, Davis RO, et al. Etiologies of preterm birth in an indigent population: Is prevention a logical expectation? Obstet Gynecol. 1991;77:343-347.

12. Goldenberg RL, Iams JD, Mercer BM, et al. The preterm prediction study: the value of new vs standard risk factors in predicting early and all spontaneous preterm births. NICHD MFMU Network. Am J Public Health. 1998;88:233-238.

13. Meis PJ, Ernest MM, Moore ML. Causes of low birth weight births in public and private patients. Am J Obstet Gynecol. 1987;956: $1165-1168$

14. Iams JD, Goldenberg RL, Meis PJ, et al. The length of the cervix and the risk of spontaneous premature delivery. $N$ Engl $J$ Med. 1996;334:562-572.

15. Tucker JM, Goldenberg RL, Moawad AH, et al. The preterm prediction study: effect of gestational age and cause of preterm birth on subsequent obstetric outcome. Am J Obstet Gynecol. 1999;181:1216-1221.

16. Goldenberg RL, et al. Vaginal fetal fibronectin measurements from 8 to 22 weeks' gestation and subsequent spontaneous preterm birth. Am J Obstet Gynecol. 2000;183:469-475.

17. Carey JC, Klebanoff MA, Hauth JC, Hillier SL, et al. Metronidazole to prevent preterm delivery in pregnant women with asymptomatic bacterial vaginosis. $N$ Engl J Med. 2000;342:534-540.
18. McDonald HM, O’Loughlin JA, Vigneswaran R, et al. Impact of metronidazole therapy on preterm birth in women with bacterial vaginosis flora (Gardnerella vaginalis): a randomised, placebo controlled trial. Br J Obstet Gynaecol. 1997;104:1391-1397.

19. Guzman ER, Rosenberg JC, Houlihan C. Ivan J, et al. R. A new method using vaginal ultrasound and transfundal pressure to evaluate the asymptomatic incompetent cervix. Obstet Gynecol. 1994;83:248-252.

20. Owen J, Yost N, Berghella V, et al. For NICHD MFMU network. Mid-Trimester endovaginal sonography in women at high risk for spontaneous preterm birth. JAMA. 2001;286:1340-1348.

21. Vayssiere C, Favre R, Audibert F, et al; for the research group in obstetrics and gynecology. Cervical length and funneling at 22 and 27 weeks to predict spontaneous birth before 32 weeks in twin pregnancies: A French prospective multicenter study. Am J Obstet Gynecol. 2002;187:1596-1604.

22. Lazar P, Gueguen S, Dreyfus J, et al. Multicentered controlled trial of cervical cerclage in women at moderate risk of preterm delivery. Br J Obstet Gynaecol. 1984;91:731-735.

23. Dor J, Shaley J, Mashiach S, et al. Elective cervical suture of twin pregnancies diagnosed ultrasonically in the first trimester following induced ovulation. Gynecol Obstet Investig. 1982;13:55-60.

24. Rush Rw, Isaacs $\mathrm{S}, \mathrm{McPherson} \mathrm{K}$, et al. A randomized controlled trial of cervical cerclage in women at high risk for preterm delivery. Br J Obstet Gynaecol. 1984;91:724-730.

25. Grant AM. Cervical cerclage. In: Enkin MW, Keirse MJNC, Renfrew MJ, Neilson JP, editors. Pregnancy and childbirth module. Cochrane Database Syst Rev. Oxford: update software; 1994. Review No. 04135.

26. Dyson DC, Danbe KH, Bamber JA, et al. Monitoring women at risk for preterm labor. N Engl J Med. 1998;338:15-19.

27. Goldenberg RL, Rouse DJ. Prevention of premature birth. NEng J Med. 1998;339:313-320.

28. Collaborative Group on Preterm Birth Prevention. Multicenter randomized controlled trial of a preterm birth prevention program. Am J Obstet Gynecol. 1993;169(2 Part 1):352-366.

29. Berkman ND, Thorp JM, Lohr KN, et al. Tocolytic treatment for the management of preterm labor: a review of the evidence. Am J Obstet Gynecol. 2003;188:1648-1659.

30. Olsen P, Laara E, Rantakillio P, et al. Epidemiology of preterm delivery in two birth cohorts with an interval of 20 years. Am J Epidemiol. 1995;142:1184-1193.

31. Morrison JJ, Rennie JM. Clinical, scientific and ethical aspects of fetal and neonatal care at extreme preterm periods of gestation. Br J Obstet Gynaecol. 1997;104:1341-1350.

32. McFarlane A, Cole S, Johnson A, et al. Epidemiology of birth before 28 weeks of gestation. Brit Med Bull. 1988;44:861-891.

33. Koupilova I, Vagero D, Leon DA, et al. Social variation in size at birth and preterm delivery in the Czech Republic and Sweden, 1989-1991. Paediatr Perinat Ep. 1998;12:7-24.

34. Mueller-Heubach E, Reddick D, Barnett B, et al. Preterm birth prevention: evaluation of a prospective controlled randomized trial. Am J Obstet Gynecol. 1989;160:1172-1178.

35. Collaborative Group on Preterm Birth Prevention. Multicenter randomized controlled trial of a preterm birth prevention program. Am J Obstet Gynecol. 1993;169:352-366.

36. McGrady GA, Sung JF, Rowley DL, et al. Preterm delivery and low birth weight among frist-born infants of black and white college graduates. Am J Epidemiol. 1992;136:266-276.

37. Mattison DR, Damus K, Fiore E, et al. Preterm delivery: a public health perspective. Paediatr Perinat Ep. 2001;15:7-16.

38. Ananth CV, Misra DP, Demissie K, et al. Rates of preterm delivery among black women and white women in the United States over two decades: an age-period-cohort analysis. Am J Epidemiol. 2001;154:657-665.

39. Vega WA, Kolody B, Hwang J, et al. Perinatal drug use among immigrant and native-born latinas. Subst Use Misuse. 1997;32:43-62. 
40. Amaro H, Whitaker R, Coffman G, et al. Acculturation and marijuana and cocaine use: Findings from HHANES 1982-84. Am J Public Health. 1990;80 Suppl:54-60.

41. Vega WA, Alderete E, Kolody B, et al. Illicit drug use among Mexicans and Mexican Americans in California: the effects of gender and acculturation. Addiction. 1998;93:1839-1850.

42. Ventura SJ, Taffel SM. Childbearing characteristics of US -and foreign-born hispanic mothers. Public Health Rep. 1985;100:647-652.

43. Guendelman S, English PB. Effect of United States residence on birth outcomes among Mexican immigrants: An exploratory study. Am J Epidemiol. 1995;142(Suppl)S30-S38.

44. Collins JW, Martin CR. Relation of traditional risk factors to intrauterine growth retardation among United States-born and foreign-born Mexican Americans in Chicago. Ethnicity Dis. 1998;8:21-25.

45. Scribner R, Dwyer JH. Acculturation and low birthweight among Latinos in the Hipanic HANES. Am J Public Health. 1989;79:1263-1267.

46. Collins JW, Shay DK. Prevalence of low birth weight among Hispanic infants with United States-born and foreign-born mothers: The effect of urban poverty. Am J Epidemiol. 1994;139:184-192.

47. Main DM, Richardson DK, Hadley CB, et al. Controlled trial of a preterm labor detection program: efficacy and costs. Obstet Gynecol. 1989;74:873-877.

48. Fangman JJ, Mark PM, Pratt L, et al. Prematurity prevention programs: An analysis of successes and failures. Am JObstet Gynecol. 1994;170:744-750.

49. Creasy RK, Gummer BA, Liggins GC. System for predicting spontaneous preterm birth. Obstet Gynecol. 1980;55:692-695.

50. Savitz DA, Blackmore CA, Thorp JM. Epidemiologic characteristics of preterm delivery: Etiologic heterogeneity. Am J Obstet Gynecol. 1991;164:467-471.

51. Migone A, Emanuel I, Mueller B, et al. Gestational duration and birthweight in white, black and mixed-race babies. Paediatr Perinat Epidemiol. 1991;5:378-391.

52. MacGregor JA, French JI, Jones W, et al. Bacterial vaginosis is associated with prematurity and vaginal fluid mucinase and sialidase: Results of controlled trial of clindamycin cream. Am J Obstet Gynecol. 1994;170:1048-1060.

53. Mclean M, Walters WAW, Smith R. Prediction and early diagnosis of preterm labor: A critical review. Obstet Gynecol Surv. 1993;48:209-225.

54. Frederick J, Anderson ABM. Factors associated with spontaneous preterm birth. Br J Obstet Gynaecol. 1976;83:342-350.

55. Carr-Hill RA, Hall M. The repetition of spontaneous preterm labor. Br J Obstet Gynaecol. 1985;92:921-928.

56. Bakketeig LS, Hoffman HJ, Harley EE. The tendency to repeat gestational age and birth weight in successive births. Am J Obstet Gynecol. 1979;135:1086-1103.

57. Wildschut HIJ, Lumey LH, Lunt PW. Is Preterm delivery genetically determined? Paediatr Perinat Epidemiol. 1991;5:363-372.

58. Johnstone F, Inglis L. Familial trend in low birthweight. BMJ 1974;3:659-661.

59. Khoury MJ, Cohen BH. Genetic heterogeneity of prematurity and intrauterine growth retardation: Clues from the old order Amish. Am J Obstet Gynecol. 1987;157:400-410.

60. Klebanoff MA, Meirik O, Berendes HW. Second-generation consequences of small for dates births. Pediatrics. 1989;84:343-347.

61. Magnus P, Bakketeig LS, Skjaerven R. Correlations of birth weight and gestational age across generations. Ann Hum Biol. 1993;20:231-238. 60a.

62. Strauss JF. Unravelling the genetics of complex disorders of reproduction. In: Coutinho EM, Spinola P, editors. Reproductive medicine: a millennium review. New York: Parthenon; 199. p. 284-287.

63. Kornman KS, Crane A, Wang HY, et al. The interleukin-1 genotype as a severity factor in adult periodontal disease. J Clin Periodontol. 1997;24:72-77.

64. Hurme M, Santtila S. IL-1 receptor antagonist (IL-1Ra) plasma levels are co-ordinately regulated by both IL-Ra and IL-1beta genes. Eur J Immunol. 1998;28:2598-2602.
65. Johnstone F, Inglis L. Familial trends in low birth weigh. BMJ. 1974;3:659-661.

66. Porter TF, Fraser AM, Hunter CY, et al. The risk of preterm birth across generations. Obstet Gynecol. 1997;90:63-67.

67. Carr-Hill RA, Hall MH. The repetition of spontaneous preterm labour. Br J Obstet Gynecol. 1985;92:921-928.

68. Bakketeig LS, Hoffman HJ, Harley EE. The tendency to repeat gestational age and birth weight in successive births. Am J Obstet Gynecol. 1979;135:1086-1103.

69. Vatten LJ, Skjaerven R. Effects on pregnancy outcome of changing partner between first two births: prospective population study. $B M J$. 2003;327:1138-1141.

70. Li DK. Changing paternity and the risk of preterm delivery in the subsequent pregnancies. Epidemiology. 1999;10:148-152.

71. Basso O, Olsen J, Christensen K. Low birth weight and prematurity in relation to paternal factors: a study of recurrence. Int J Epidemiol. 1999;28:695-700.

72. Amon E. Preterm Labor. In: Reece EA, Hobbins JC, editors Medicine of the fetus and mothers. Philadelphia: Lippincott-Raven: 1999;p. 1529-79.

73. Fuchs F, Stakeman G. Treatment of threatened premature labor with large does of progesterone. Am J Obstet Gynecol. 1960;79:172.

74. Fuchs AR, Fuchs F. Endocrinology of human parturition: a review. Br J Obstet Gynaecol. 1984;91:948-967.

75. Csapo AI, The "see-saw" theory of parturition. In: O'Connor M, Knight J, (eds.) The fetus and birth. New York: Elsevier, 1977;p 159-210.

76. Liggins GC, Thorburn GD. Initiation of parturition. In: Lamming GE, (ed.) Marshall's physiology of reproduction. London: Chapman and Hall, 1994;p. 863-1002.

77. Flint APP, Anderson ABM, Steele PA, et al. The mechanisms by with foetal cortiosol controls the onset of parturition in the sheep. Biochem Soc Trans. 1975;3:1189-1194.

78. Lye SJ, Porter DG, Demonstration that progesterone "blocks" uterine activity in the ewe in vivo by a direct action on the myometrium. J Reprod Fertil. 1978;52:87-94.

79. Tulchinsky D, Hobel CJ, Yeager E, et al. Plasma estrone, estradiol, estriol, progesterone, and 17-hydroxyprogseterone in human pregnancy I. Normal pregnancy. Am J Obstet Gynecol. 1972;112:1095-1100.

80. Walsh SW, Stanczyk FZ, Novy MJ. Daily hormonal changes in the maternal, fetal and amniotic fluid compartments before parturition in a primate species. J Clin Endocrinol Metab. 1984;58:629-639.

81. Avrech OM, Golan A, Weinraub Z, et al. Mifepristone (RU486) alone or in combination with prostaglandin analogue for termination of early pregnancy: A review. Fertil Steril. 1991;56:385-393.

82. Haluska GJ, Novy MJ. Hormonal modulation of uterine activity during primate parturition. Semin Reprod Endocrinol. 1993;11:261-271.

83. Selinger M, MacKenzie IZ, Gillmer MD, et al. Progesterone inhibition in mid-trimester termination of pregnancy: Physiological and clinical effects. Br J Obstet Gynaecol. 1987;94:218-222.

84. Haluska GJ, Cook MJ, Novy MJ. Inhibition and augmentation of progesterone production during pregnancy: effects of parturition and rhesus monkeys. Am J Obstet Gynecol. 1997;176:682-691.

85. Lye S. The initiation and inhibition of labour-toward a molecular understanding. Semin Reprod Endocrinol. 1994;12:284-294.

86. Westphal U, Stroupe SD, Cheng SL. Progesterone binding to serum proteins. Ann NY Acad Sci. 1977;286:10-28.

87. McGarrigle HH, Lachelin GC. Increasing saliva (free) oestriol to progesterone ration in late pregnancy: a role for oestriol in initiating spontaneous labor in man? Br Med J Clin Res Ed. 1984;289:457-459.

88. Mitchell BF, Wong S. Changes in $17 \mathrm{~B}, 20$-alpha-hydroxysteroid dehydrogenase activity supporting an increase in the estrogen/ progesterone ratio of human fetal membranes at parturition. Am JObstet Gynecol. 1993;68:1377-1385.

89. Progesterone therapy. Progesterone ... what is it? Accessed December 21, 2006. Available at: http//:www.progesteronetherapy.com/.

90. Murray JL, Natural progesterone: what role in women's health care? Women's Health Primary Care. 1998;1:671-687. 
91. Onsrud M, Paus E, Haug E, et al. Intraumuscular administration of hydroxyprogesterone caproate in patients with endometrial carcinoma. Pharmacokinetics and effects on adrenal function. Acta Obstet Gynecol Scand. 1985;64:519-523.

92. von Eye Corleta H, Capp E, Ferreira MBC. Pharmacokinetics of natural progesterone vaginal suppository. Gynecol Obstet Invest. 2004;58:105-108.

93. Di Renzo GC, Mattei A, Gojnic M, et al. Progesterone and pregnancy. Curr Opin Obstet Gynecol. 2005;17:598-600.

94. Penzias AS, Alper MM. Luteal support with vaginal micronized progesterone gel in assisted reproduction. Reprod Biomed Online. 2003;6:287-295.

95. Posaci C, Smitz J, Camus M, et al. Progesterone for the luteal support of assisted reproductive technologies: clinical options. Human Reprod. 2000;15(suppl 1):129-148.

96. LeVine L. Habitual abortion: a controlled clinical study of pregestational therapy. West J Surg Obstet Gynecol. 1964;72:3036.

97. Papiernik E. Double blind study of an agent to prevent pre-term delivery among women at increased risk. Schering ed. Series 4, 1970; p. $65-68$.

98. Johnson JWC, Austin KL, Jones GS, et al. Efficacy of $17 \alpha$-hydroxyprogesterone caproate in the prevention of premature labor. N Engl J Med. 1975;293:675-680.

99. Yemini M, Borenstein R, Dreazen E, et al. Prevention of premature labor by 17 alphahydroxyprogesterone caproate. Am J Obstet Gynecol. 1985;151:574-577.

100. Hartikainen-Sorri A-L, Kauppila A, Tuimala R. Inefficacy of $17 \alpha$-hydroxyprogesterone caproate in the prevention of prematurity in twin pregnancy. Obstet Gynecol. 1980;56:692-695.

101. Hauth JC, Gilstrap LC III, Brekken AL, et al. The effect of 17 alphahydroxyprogestrone caproate on pregnancy outcome in an active-duty military population. Am J Obstet Gynecol. 1983;146:187-190.

102. Keirse MJNC. Progesterone administration in pregnancy may prevent preterm delivery. Br J Obstet Gynaecol. 1990;97:149-154.

103. da Fonseca E, Bittar RE, Carvalho MHB, et al. Prophylactic administration of progesterone by vaginal suppository to reduce the incidence of spontaneous Preterm birth in women at increased risk: A randomized placebo-controlled double-blind study. Am J Obstet Gynecol. 2003;188:419-424.

104. Meis PJ, Klebanoff M, Thom E, et al. NICHD MFMU Network. Prevention of recurrent preterm delivery by 17 alpha-hydroxyprogesterone caproate. N Engl J Med. 2003;348(24):2379-2385.
105. Spong CY, Meis PJ, Thom EA, et al. Progesterone for prevention of recurrent preterm birth: Impact of gestational age at previous delivery. Am J Obstet Gynecol. 2005;193:1127-1131.

106. O’Brien JM, Adair CD, Lewis, DF, et al. Progesterone vaginal gel for the reduction of recurrent preterm birth: Primary results from a randomized, double blind, placebo controlled trial. Ultrasound Obstet Gynecol. 2007;30:687-696.

107. Rouse D, Caritis S, Peaceman AM, et al. NICHD MFMU Network. A trial of 17-Alpha-hydorxyprogesterone Caproate to prevent prematurity in Twins. N Engl J Med. 2007;357:454-461.

108. da Fonseca EB, Celik E, Paire M, et al. for the Fetal Medicine Foundation, Second Trimester Screening Group. Progesterone and the Risk of Preterm Birth Among Women with a Short Cervix. N Engl J Med. 2007;357:462-469.

109. Rebarber A, Ferrara LA, Hanley ML, et al. Increased recurrence of preterm delivery with early cessation of 17-alpha-hydroxyprogeterone caproate. Am J Obstet Gynecol. 2007;196:224.e1-24.e4.

110. How HY, Barton J, Istwan N, et al. Prophylaxis with 17 Alphahydroxyprogesterone Caproate for Prevention of Recurrent Preterm Delivery: Does Gestational Age at Initiation of Treatment Matter? Am J Obstet Gynecol. 2007;197:260.e1-260.e4.

111. FDA issues NDA 21-945. Proposed Indication. "Gestiva is indicated for the prevention of preterm birth in ... www.fda.gov/ohms/dockets/ ac/06/briefing/2006-4227B1-02-01-FDA-backgroung.pdf.

112. Heinonen OP, Slone D, Shapiro S. Birth defects and Drugs in Pregnancy. Littleton, Mass: PSG Publishing; 1977.

113. Crossley KJ, Nicol MB, Hisrst JJ, et al. Suppression of arousal by progesterone in fetal sheep. Reprod Fertil Dev. 1997;9:767-773.

114. Nicol MB, Hirst JJ, Walker D, et al. Effect of alteration of maternal plasma progesterone concentration on fetal behavioural state during late gestation. J Endocrinol. 1997;152:379-386.

115. Northen AT, Norman GS, Anderson K, et al. for NICHD MFMU Network. Follow-up of children exposed to 17 Aalpha-hydroxyprogesterone caproate compared with placebo. Obstet Gynecol. 2007;110:865-872.

116. Brancazio LR, Murtha AP, Heine RP. Prevention of recurrent preterm delivery by 17 alpha-hydroxyprogesterone caproate. $N$ Engl J Med. 2003;349:1987-1988.

117. American College of Obstetricians and Gynecologists. ACOG committee opinion. Use of progesterone to reduce preterm birth. Obstet Gynecol. 2003;102:1115-1116. 